\title{
Job Selection After Orthopedic Surgery Training: Why Are Our Trainees Failing to Select the Right Job?
}

Joseph L. Laratta ${ }^{1}$, Jeffrey L. Gum ${ }^{1}$, Jamal N. Shillingford ${ }^{1}$, Hemant Reddy ${ }^{2}$, Ronald A. Lehman ${ }^{3}$, Charles H. Crawford ${ }^{4}$, Steven D. Glassman ${ }^{1}$, Leah Carreon ${ }^{5}$

1. Orthopaedics, Norton Healthcare, Norton Leatherman Spine Center, Louisville, USA 2. Orthopaedics, Northeast Ohio Medical University (NEOMED), Rootstown, USA 3. Orthopaedics, Columbia Spine Hospital, New York, USA 4. Orthopaedic Surgery, University of Louisville, Louisville, USA 5. Research, Norton Healthcare, Norton Leatherman Spine Center, Louisville, USA

Corresponding author: Leah Carreon, leah.carreon@nortonhealthcare.org

\section{Abstract}

A survey was administered to a random sampling of the American Academy of Orthopaedic Surgeons (AAOS) members to determine the rate at which recently trained orthopedic surgeons switch their first job and to identify factors affecting the job selection process.

There were 351 (21\%) respondents. Respondents considered practice location (41\%), practice type (28\%), and family proximity (23\%) as most important while research opportunity (54\%) and signing bonus (33\%) were considered least important in their first job. Half of the respondents (51\%) left their first job before the completion of their fifth year; most left for financial reasons (34\%) or because the practice was not as advertised (31\%). Many (53\%) stated they had minimal training in selecting their first job and most (88\%) felt inadequately prepared for the business side of orthopedics. Further studies are needed to evaluate the high rate of initial post-training job attrition to decrease the personal and societal costs of this phenomenon.

Received 05/11/2019

Review began 05/14/2019 Review ended 07/03/2019 Published 08/31/2019

๑) Copyright 2019 Laratta et al. This is an open access article distributed under the terms of the Creative Commons Attribution License CC-BY 3.0., which permits unrestricted use, distribution, and reproduction in any medium, provided the original author and source are credited.
Categories: Medical Education, Orthopedics

Keywords: systems-based practice, orthopedic surgery training, medical education, job selection, job attrition

\section{Introduction}

Professional and financial stresses accompany the training of an orthopedic surgeon. Anecdotally, more than half of orthopedic trainees switch jobs within a few years of starting practice. Furthermore, orthopedic surgeon burnout ranges from 32\% to 59.6\% [1-2] Despite this, orthopedic surgeons have greater job satisfaction as compared to general surgeons [2]. It remains unclear as to why a large proportion of orthopedic surgeons change initial jobs.

The primary purpose of this study was to determine what orthopedic surgeons consider the most important factors in the job selection process and what factors are associated with changing jobs so quickly after completing training. This may help future orthopedic trainees navigate a successful career pathway by addressing the job attrition phenomenon, allowing them to make well-informed decisions [3-4].

\section{Materials And Methods}

A web-based survey was developed using SurveyMonkey, a platform for online data collection (California, US). The survey consisted of 26 questions, collecting data on demographics, details regarding the respondent's first and second jobs, and specifics of the job-switch process. A link to the survey was emailed to all 1,656 US-based members of the American Academy of Orthopaedic Surgeons (AAOS) between August and September 2017 with 311 (19\%) physicians responding.

Statistical analyses were performed using SPSS (IBM v24.0, Armonk, NY, US). Independent sample t-tests were used for continuous data. Fisher exact tests were used for categorical variables. Associations between variables were examined using Pearson correlations. Statistical significance was defined as $\mathrm{p}<0.05$.

\section{Results}

Of the 311 respondents, half were still at their first job and the other half had already switched jobs. Around half ( $46 \%$ ) were more than 15 years post-training, $20 \%$ were $10-15$ years, $22 \%$ were five to 10 years, and $12 \%$ were less than five years post-training (Table 1 ). 


\section{Cureus}

\begin{tabular}{|c|c|c|c|c|}
\hline \multicolumn{5}{|c|}{ Training and practice type of respondents } \\
\hline & Yes & No & Total & $\mathrm{p}$-value \\
\hline $\mathrm{N}$ & $154(50 \%)$ & $157(50 \%)$ & 311 & \\
\hline Years post-training & & & & 0.016 \\
\hline $0-1$ years & $2(1 \%)$ & $0(0 \%)$ & $2(1 \%)$ & \\
\hline $1-2$ years & $5(3 \%)$ & $2(1 \%)$ & $7(2 \%)$ & \\
\hline $2-3$ years & $3(2 \%)$ & $1(1 \%)$ & $4(1 \%)$ & \\
\hline $3-4$ years & $9(6 \%)$ & $3(2 \%)$ & $12(4 \%)$ & \\
\hline 4-5 years & $10(6 \%)$ & $6(4 \%)$ & $16(5 \%)$ & \\
\hline $5-10$ years & $40(26 \%)$ & $27(17 \%)$ & $67(22 \%)$ & \\
\hline $10-15$ years & 29 (19\%) & $32(20 \%)$ & $61(20 \%)$ & \\
\hline$>15$ years & $56(36 \%)$ & $86(55 \%)$ & $142(46 \%)$ & \\
\hline Fellowship-trained & $136(88 \%)$ & $131(83 \%)$ & $267(86 \%)$ & 0.256 \\
\hline Practice type & & & & 0.802 \\
\hline Private (same specialty group) & $74(48 \%)$ & $70(45 \%)$ & $144(46 \%)$ & \\
\hline Academic & $27(18 \%)$ & $31(20 \%)$ & $58(19 \%)$ & \\
\hline Hospital-employed & $18(12 \%)$ & $13(8 \%)$ & $31(10 \%)$ & \\
\hline Private (multi-specialty group) & $15(10 \%)$ & $14(9 \%)$ & $29(9 \%)$ & \\
\hline Other (please specify) & $9(6 \%)$ & $12(8 \%)$ & $21(7 \%)$ & \\
\hline Private (solo) & $7(5 \%)$ & $12(8 \%)$ & $19(6 \%)$ & \\
\hline Hybrid & $4(3 \%)$ & $5(3 \%)$ & $9(3 \%)$ & \\
\hline
\end{tabular}

TABLE 1: Training and practice type of respondents

As expected, a larger proportion of respondents that have been in practice longer had switched jobs $(\mathrm{p}=0.016)$. The majority of surgeons completed fellowship training $(85 \%)$, which was not associated with switching jobs ( $\mathrm{p}=0.256$ ). Almost all the respondents who did not complete fellowship were 15 years (38) or 10-15 years (6) post-training. Single-specialty private group practice accounted for $46 \%$ of first jobs, followed by academic (19\%), hospital-based (10\%), and private practice in a multispecialty group (9\%).

Respondents were asked to rank the factors ( $1=$ most important to $7=$ least important) they considered while deciding on both their first job and second jobs. The factors that respondents considered to be important for their first job were similar between those who changed and those that did not change their first job (Table 2). 


\section{Cureus}

Factors ranked by importance ( $1=$ most important to $7=$ least important) in selecting first and second jobs

\begin{tabular}{|c|c|c|c|}
\hline & \multicolumn{2}{|c|}{ First Job } & \multirow[t]{2}{*}{ Second Job } \\
\hline & Yes & No & \\
\hline $\mathrm{N}$ & 154 & 157 & 157 \\
\hline \multicolumn{4}{|l|}{ Ranked by importance } \\
\hline Geography (location) & 2.2 & 2.2 & 2.5 \\
\hline Practice type & 2.5 & 2.8 & 2.4 \\
\hline Family proximity & 3.0 & 3.4 & 3.5 \\
\hline Potential income & 3.6 & 3.8 & 3.7 \\
\hline Starting income & 4.5 & 4.1 & 4.0 \\
\hline Signing bonus & 6.1 & 5.9 & 6.0 \\
\hline Research opportunity & 6.1 & 5.8 & 5.9 \\
\hline
\end{tabular}

TABLE 2: Factors ranked by importance ( $1=$ most important to $7=$ least important) in selecting first and second jobs

The most important considerations were location, practice type, and family proximity. For those that switched jobs, practice type became a more important consideration than location. Most respondents did not stay close to their residency or fellowship program either for their first or second jobs (Table 3).

Distance from training program to first and second jobs

\begin{tabular}{|c|c|}
\hline & Proximity to first job \\
\hline Proximity to second job & Joined training program \\
\hline Joined training program & 1 \\
\hline $1-50$ miles & 1 \\
\hline $50-150$ miles & 0 \\
\hline 150 miles or more & 3 \\
\hline
\end{tabular}

$\begin{array}{lll}0-50 \text { miles } & 50-150 \text { miles } & >150 \text { miles } \\ 1 & 0 & 5 \\ 8 & 1 & 5 \\ 1 & 6 & 4 \\ 6 & 2 & 77\end{array}$

TABLE 3: Distance from training program to first and second jobs

Only a small proportion of respondents answered that they had adequate guidance in terms of job selection during their training, and this proportion was similar between those that switched (12\%) and those that did not (12\%) switch jobs (Table 4 ). 


\section{Cureus}

\begin{tabular}{|c|c|c|c|c|}
\hline \multicolumn{5}{|c|}{ Amount of business education respondents received during training } \\
\hline & \multicolumn{2}{|c|}{ Still at First Job } & \multirow[b]{2}{*}{ Total } & \\
\hline & Yes & No & & \\
\hline \multicolumn{5}{|c|}{ Guidance during training } \\
\hline None & $36(23 \%)$ & $67(43 \%)$ & $103(33 \%)$ & 0.001 \\
\hline Minimal & $92(60 \%)$ & $71(45 \%)$ & $163(52 \%)$ & \\
\hline Adequate & $26(17 \%)$ & $19(12 \%)$ & $45(14 \%)$ & \\
\hline \multicolumn{5}{|c|}{ Number of contracts reviewed } \\
\hline 0 & $7(5 \%)$ & $16(10 \%)$ & $23(7 \%)$ & 0.235 \\
\hline $1-2$ & 76 (49\%) & $75(48 \%)$ & $151(49 \%)$ & \\
\hline $3-4$ & $64(42 \%)$ & $55(35 \%)$ & $119(38 \%)$ & \\
\hline $5-6$ & $5(3 \%)$ & $6(4 \%)$ & $11(4 \%)$ & \\
\hline$>6$ & $2(1 \%)$ & $5(3 \%)$ & $7(2 \%)$ & \\
\hline \multicolumn{5}{|l|}{ Contract review } \\
\hline Contract attorney & $88(57 \%)$ & $87(55 \%)$ & $175(56 \%)$ & 0.168 \\
\hline No one & $31(20 \%)$ & $44(28 \%)$ & $75(24 \%)$ & \\
\hline Other & $35(23 \%)$ & 26 (17\%) & $61(20 \%)$ & \\
\hline
\end{tabular}

TABLE 4: Amount of business education respondents received during training

The proportion of respondents who answered that they had no guidance was smaller in those who were still at their first job. The proportion of respondents who sought the assistance of a contract lawyer was similar between the two groups. Interestingly, the respondents who had answered that they had no guidance also had a smaller number who consulted a contract attorney and a larger number who did not consult anyone before signing their first contract (Table 5).

Amount of business education and contract review Amount of business education

Contract reviewed with

Contract attorney

No one

Other
None

$43(42 \%)$

$40(39 \%)$

$20(19 \%)$

\section{Minimal}

$101(62 \%)$

$28(17 \%)$

$34(21 \%)$
Adequate

0.000

TABLE 5: Amount of business education and contract review

\section{Discussion}

This is the first study to identify factors that lead to a recently trained orthopedic surgeon choosing their first job as well as factors that lead to switching jobs. About half of the respondents switched jobs. As expected, respondents who more recently finished their training were still at their first jobs, as most respondents switched jobs within five years after their training.

Whether or not they switched jobs, practice location and practice type were the most important factors in choosing their first job post-training. For those that switched jobs, these two were still the most important factors, but practice type was more important than practice location. The finding that one of the more 
common reasons for leaving their first job was that the practice was not as advertised is consistent with this finding, possibly indicating that surgeons learned from the reasons they left their first job or found more suitable second jobs. However, the proportion of respondents within each practice type were similar between those who switched and those who did not switch jobs. This may be reflective of the availability of these practice types and not necessarily the choice of the respondents.

It is clear that the majority of trainees did not see any value in staying close to their residency or fellowship program when considering their job opportunities and that the choice of practice location probably includes other factors that need to be considered such as the quality of schools for children, the size of the community, and the type of activities that are available.

Perhaps the most important finding in this study is that a large majority of respondents did not feel that they had enough guidance regarding the business side of the practice of orthopedics. It is clear that the training programs currently in place do not adequately prepare the residents or fellows, as half of the respondents did not remain at their first job, only 56\% consulted a lawyer to review their contract, and $26 \%$ did not consult anyone.

There seems to be a large disparity in orthopedic residency and fellowship training to prepare future surgeons for the realities of practice. These are concerns that can likely be readily addressed. During the final years of orthopedic training, job evaluation and financial didactics may be provided by those in the field with experience. Future planning and consideration regarding career paths may be encouraged earlier in orthopedic training. The current study indicates that more open business discussions in training, additional training within residency or fellowship programs, and a better understanding of the healthcare system are all possible avenues of improvement. Medical student and resident career paths are influenced by their personal interests, salary potential, debt, working hours, and call responsibilities [5-7]. However, their career paths are most influenced by mentors and prior clinical experiences [8], further emphasizing the need for additional training and mentorship during residency focused on job selection.

The primary limitations of this study are inherent to its design as a survey-based study. The response rate of $19 \%$ is comparable to other physician surveys in general [9-10]. Although not all aspects of the factors influencing job selection can be studied, the current study attempted to analyze the most common. Specifically, this study did not examine burnout and its effect on the job attrition phenomenon. Additionally, the effect of global changes on the field of orthopedics and the medical landscape over time were not analyzed.

\section{Conclusions}

When orthopedic surgeons select their first jobs, practice location, practice type, and family proximity are most important. Half of the respondents left their first post-training job, with the majority leaving within the first five years. The vast majority (86\%) of survey respondents reported minimal to no education regarding job selection. It is unclear why orthopedic trainees are being poorly educated regarding job selection, and further study into the high rate of initial post-training job attrition may decrease the personal and societal costs of this phenomenon.

\section{Additional Information \\ Disclosures}

Human subjects: Consent was obtained by all participants in this study. University of Louisville Institutional Review Board issued approval 15.0490. This study was reviewed by the University of Louisville Institutional Review Board and approved through the Expedited Review Procedure. Animal subjects: All authors have confirmed that this study did not involve animal subjects or tissue. Conflicts of interest: In compliance with the ICMJE uniform disclosure form, all authors declare the following: Payment/services info: Funding for this study was received from the Fischer Owen Orthopaedic Fund. Financial relationships: Laratta, Gum, Lehman, Crawford, Carreon, Glassman declare(s) a grant, non-financial support, employment and royalties from Acuity, Cingulate Therapeutics, DePuy, Stryker, K2M, Evolution Spine, PEAK neuromonitoring, Alphatec, Nuvasive, Pfizer. JLL, JNS, JLG, CHC, SDG, and LYC are employees of Norton Healthcare; JLL JLG receives royalties and consulting fees from Acuity, stock options from Cingulate Therapeutics, speaker fees from Depuy and Stryker, consulting fees from K2M, Mazor, Medtronic and receives consulting fees from Evolution Spine and PEAK neuromonitoring. CHC receives royalties, consulting fees, and speaker fees from Alphatec spine, consulting fees, speaker fees from Medtronic and Nuvasive, committee member NASS, SRS, receives publishing royalties from Springer. LYC receives funds for travel from the University of Southern Denmark; University of Louisville; Consulting fees from AO Spine, Member, Editorial Advisory Board, Spine Deformity, The Spine Journal and Spine; Member University of Louisville IRB; Research Committee SRS. Institution receives funds from Pfizer, TSRH, SRS, OREF, and ISSG. RAL receives consulting fees from Medtronic, speaker's fees from DePuy, Medtronic, and Stryker. Other relationships: All authors have declared that there are no other relationships or activities that could appear to have influenced the submitted work. 


\section{Cureus}

\section{References}

1. Shanafelt TD, Hasan O, Dyrbye LN, Sinsky C, Satele D, Sloan J, West CP: Changes in burnout and satisfaction with work-life balance in physicians and the general US working population between 2011 and 2014. Mayo Clin Proc. 2015, 90:1600-1613. 10.1016/j.mayocp.2015.08.023

2. Balch CM, Shanafelt TD, Sloan JA, Satele DV, Freischlag JA: Distress and career satisfaction among 14 surgical specialties, comparing academic and private practice settings. Ann Surg. 2011, 254:558-568. 10.1097/SLA.0b013e318230097e

3. Haas JS, Cook EF, Puopolo AL, Burstin HR, Cleary PD, Brennan TA: Is the professional satisfaction of general internists associated with patient satisfaction?. J Gen Intern Med. 2000, 15:122-128. 10.1046/j.15251497.2000.02219.x

4. Leigh JP, Tancredi DJ, Kravitz RL: Physician career satisfaction within specialties. BMC Health Serv Res. 2009, 9:166. 10.1186/1472-6963-9-166

5. Greysen SR, Chen C, Mullan F: A history of medical student debt: observations and implications for the future of medical education. Acad Med. 2011, 86:840-845.

6. Johnson JP, Cassidy DB, Tofte JN, Bariteau JT, Daniels AH: Orthopedic surgery resident debt load and its effect on career choice. Orthopedics. 2016, 39:438-443. 10.3928/01477447-20160315-01

7. Morrell NT, Mercer DM, Moneim MS: Trends in the orthopedic job market and the importance of fellowship subspecialty training. Orthopedics. 2012, 35:555-560. 10.3928/01477447-20120327-13

8. Salsberg ES, Grover A, Simon MA, Frick SL, Kuremsky MA, Goodman DC: An AOA critical issue. Future physician workforce requirements: implications for orthopaedic surgery education. J Bone Joint Surg Am. 2008, 90:1143-1159. 10.2106/JBJS.G.01305

9. Kellerman SE, Herold J: Physician response to surveys. A review of the literature . Am J Prev Med. 2001, 20:61-67.

10. Asch DA, Jedrziewski MK, Christakis NA: Response rates to mail surveys published in medical journals . J Clin Epidemiol. 1997, 50:1129-1136. 10.1016/S0895-4356(97)00126-1 